\title{
Eksplorasi Nilai-Nilai Keislaman dan Etika Lingkungan pada Komunitas Peduli Sungai di Kecamatan Cluwak Pati
}

\author{
Irma Yuniar Wardhani, Noor Jannah, \& Cheppy Fadella \\ Institut Agama Islam Negeri Kudus \\ Email: irmayuniar@iainkudus.com
}

\begin{abstract}
ABSTRAK
Penelitian ini merupakan penelitian eksplorasi lapangan dengan pendekatan kualitatif deskriptif. Penentuan subyek penelitian dilakukan dengan purposive sampling. Pihak yang dijadikan sumber data dalam penelitian ini adalah mereka yang mengetahui, memahami, dan mengalami fokus kajian penelitian ini, yaitu yang mengetahui, memahami sejarah dan pelaksanaan kegiatan sebagai upaya pengamalan nilai-nilai keislaman dan etika lingkungan pada komunitas peduli sungai di kecamatan Cluwak, Pati. Teknik pengumpulan data yang digunakan dalam penelitian ini, yaitu: teknik observasi, teknik wawancara dan dokumentasi. Data-data yang diperoleh kemudian dianalisis dalam beberapa tahap yaitu: tabulasi dan klasifikasi data, reduksi data, interpretasi data dan penyimpulan data. Hasil penelitian diperoleh bahwa adanya fenomena penumpukan sampah di sekitar jembatan Kebolanjam yang berada di titik 500 m sungai B, komunitas peduli sungai mengambil langkah operasional yang efektif dan kreatif untuk mengatasi pencemaran sampah di sekitar aliran sungai sebagai wujud nyata etika terhadap lingkungan dengan konsep bersih dan elok serta tidak melupakan upaya untuk perbaikan sikap masyarakat melalui internalisasi nilai-nilai islam (nilai ilahiyah dan insaniyah) melalui majelis taklim dan peningkatan pendidikan agama dalam berbagai forum atau kegiatan masyarakat desa Ngablak secara kontinyu.
\end{abstract}

Kata kunci: Etika Lingkungan, Komunitas Peduli Sungai, Nilai-Nilai Keislaman.

\section{ABSTRACT}

This research is a field exploration research with descriptive qualitative approach. Determination of research subjects was done by purposive sampling. The parties used as data sources in this study are those who know, understand, and experience the focus of this research study, those who know and understand the history and implementation of activities as an effort to practice Islamic values and environmental ethics in river caring communities in Cluwak sub-district, Pati. Data collection techniques used in this study: observation, interview and 
documentation. The data obtained are then analyzed in several stages: data tabulation and classification, data reduction, data interpretation and data conclusions. The results showed that there is a phenomenon of garbage accumulation around the Kebolanjam bridge which is at the $500 \mathrm{~m}$ point of river $B$, the river caring community takes effective and creative operational steps to overcome the garbage pollution around the river flow as a tangible manifestation of ethics towards the environment with a clean and beautiful concept. Community does not forget the effort to improve people's attitudes through internalizing the values of Islam (ilahiyah dan insaniyah value) through majelis taklim and increasing religious education in various forums or activities of Ngablak communities continuously.

Keywords: Environmental Ethics, Islamic Values, River Caring Community.

\section{PENDAHULUAN}

Islam adalah agama yang paling sempurna yang telah diturunkan Allah untuk menjadi rahmat bagi seluruh alam. Keberadaan agama islam seyogyanya tidak hanya dikenal dan dianut oleh masyarakat banyak, tetapi yang paling penting adalah bentuk internalisasi nilai-nilai keislaman yang berupa pemahaman, penghayatan dan pengamalan oleh masyarakat. Nilai-nilai yang terkandung dalam islam adalah fondasi yang harus tertanam dalam diri umat islam, mengingat dewasa ini nilai-nilai keislaman mulai terkikis disebabkan oleh gaya hidup dan perkembangan zaman yang semakin sekuler. Nilai-nilai ini tidak dapat serta merta tumbuh dalam diri seseorang tanpa adanya kesadaran dan tekad yang kuat. Oleh karena itu, perlu adanya komitmen dan perhatian yang lebih terhadap segala bentuk upaya untuk mewujudkan kembali nilai-nilai keislaman dalam masyarakat.

Ada begitu banyak upaya untuk dapat mewujudkan internalisasi nilai-nilai keislaman yang dapat dilakukan. Bentuk penanaman nilai-nilai keislaman yang paling dekat dengan kehidupan masyarakat yaitu melalui usaha pemeliharaan kebersihan lingkungan. Ironisnya, sebagian besar masyarakat belum memiliki kesadaran terhadap kebersihan lingkungannya. Banyak fakta dan data yang menunjukkan bahwa kesadaran masyarakat Indonesia yang mayoritas muslim tidak peka terhadap kebersihan lingkungannya. Keadaan ini diperburuk dengan perilaku membuang sampah dan kotoran di sungai maupun di jalan raya. Hal tersebut jelas melanggar etika lingkungan dan syariat islam. Padahal, banyak ayat 
Al-quran dan hadist yang menjelaskan tentang pentingnya menjaga kebersihan, karena begitu pentingnya kebersihan menurut islam, sehingga orang yang membersihkan diri atau mengusahakan kebersihan akan dicintai oleh Allah. Selain itu, secara khusus Rasulullah SAW memberikan perhatian mengenai kebersihan.

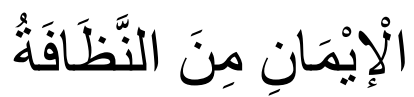

Artinya : "Kebersihan itu sebagian dari iman". (HR. Ahmad)

Islam telah banyak mengajarkan kita untuk selalu menjaga kebersihan dalam segala bentuk aktivitas. Maka dari itu, seharusnya telah menjadi kewajiban kita sebagai umat islam untuk memiliki etika yang baik terhadap lingkungan dengan selalu memperhatikan kebersihan dan keindahan lingkungan sekitar kita.

Etika lingkungan merupakan suatu sikap dan tanggung jawab yang harus dimiliki manusia terhadap lingkungan. Etika lingkungan mulai menjadi pembahasan penting dewasa ini, karena terjadi peningkatan kerusakan lingkungan hidup dan ekologi manusia, baik di negara-negara maju maupun negara berkembang termasuk Indonesia (Rusdina, 2015). Kerusakan lingkungan yang terjadi berdampak pada aspek kesehatan dan kehidupan sosial serta budaya masyarakat. Menurut Desfandi (2015), salah satu komitmen masyarakat dan pemerintah internasional dalam menjaga bumi dari pencemaran dan kerusakan adalah melalui pelaksanaan pendidikan lingkungan hidup (Environment Education). Pendidikan tersebut dapat dilakukan oleh perorangan maupun kolektif dalam mencari alternatif atau memberi solusi terkait permasalahan lingkungan di sekitarnya.

Sehubungan dengan penjelasan tersebut, adapun hal yang perlu mendapat perhatian lebih berkaitan dengan internalisasi nilai-nilai keislaman dan etika lingkungan, yaitu adanya suatu komunitas peduli sungai yang terletak di kecamatan Cluwak, kabupaten Pati. Komunitas peduli sungai yang ada di daerah Cluwak merupakan salah satu bentuk komunitas peduli lingkungan yang memiliki tekad dan komitmen yang kuat dalam menjaga kebersihan dan keindahan sekitar sungai. Uniknya, komunitas tersebut lahir ditengah-tengah masyarakat pedesaan yang tidak banyak mendapat pengetahuan tentang etika lingkungan, akan tetapi 
mereka mencoba menerapkan gaya hidup bersih dan sehat sesuai syariat islam dalam menjaga lingkungan sekitar sungai.

\section{METODE PENELITIAN}

Jenis penelitian ini merupakan penelitian eksplorasi lapangan dengan pendekatan kualitatif deskriptif. Pendekatan ini menggambarkan keadaan objek yang diteliti berdasarkan fakta yang ada, kemudian dianalisa menjadi satu informasi yang bermakna dan memiliki arti.

Pihak yang dijadikan sumber data dalam penelitian ini adalah mereka yang mengetahui, memahami, dan mengalami fokus kajian penelitian ini, yaitu yang mengetahui, memahami sejarah dan pelaksanaan kegiatan sebagai upaya pengamalan nilai-nilai keislaman dan etika lingkungan pada komunitas peduli sungai di kecamatan Cluwak, Pati. Penentuan subyek penelitian dilakukan dengan purposive sampling. Adapun purposive sampling digunakan untuk menentukan masyarakat yang terlibat dalam komunitas peduli sungai di kecamatan Cluwak Pati. Teknik Pengumpulan Data yang digunakan dalam penelitian ini, antara lain:

1. Teknik Observasi

Observasi (observation) merupakan suatu teknik atau cara mengumpulkan data dengan mengadakan pengamatan terhadap kegiatan yang sedang berlangsung (Sukmadinata, 2006). Pada hal ini, penulis melakukan observasi partisipan dan non partisipan. Observasi di lakukan guna mengadakan pengamatan dan mendapatkan data secara luas tentang kegiatan yang dilakukan komunitas peduli sungai dalam menanamkan nilai-nilai keislaman dan etika lingkungan.

2. Teknik Wawancara

Wawancara atau interview adalah sebuah dialog yang dilakukan oleh pewancara (interviewer) untuk memperoleh informasi dari narasumber (Arikunto, 2006). Jenis wawancara yang digunakan adalah wawancara bebas terpimpin yaitu dalam pelaksanaan wawancara, pewancara membawa pedoman yang hanya merupakan garis besar tentang hal yang akan ditanyakan. Hasil wawancara kemudian ditranskrip, dipilih data yang dibutuhkan untuk kemudian dianalisa. 
3. Dokumentasi

Metode dokumentasi yaitu mencari data mengenai hal-hal atau variabel yang berupa catatan, transkrip, buku, surat kabar, majalah, notulen rapat, agenda dan sebagainya. Dokumentasi yang diperlukan diantaranya profil komunitas, program komunitas, administrasi pelaksanaan kegiatan peduli sungai, dan jadwal kegiatan komunitas.

Setelah data terhimpun, maka diklasifikasikan sesuai dengan masalah yang akan dibahas dan dianalisis isinya, dibandingkan data yang satu dengan data yang lainnya, kemudian diinterpretasikan dan akhirnya diberikan kesimpulan. Data yang diperoleh dalam penelitian ini berupa hasil wawancara dan observasi berkaitan dengan informasi kegiatan komunitas.

\section{HASIL DAN PEMBAHASAN}

\section{A. Kondisi Sungai dan Lingkungan di Sekitar Sungai Silungonggo Ngablak}

Desa Ngablak merupakan salah satu desa di kecamatan Cluwak, Kabupaten Pati yang terletak di salah satu kaki pegunungan Muria. Mata pencaharian sebagian besar penduduk desa Ngablak adalah sebagai petani, peternak, pedagang dan pegawai. Desa Ngablak dilalui oleh beberpa sungai yang bermuara ke Laut Jawa melalui sungai Silungonggo.

Kondisi sungai Silungonggo di Desa Ngablak dulunya terdiri dari batuan-batuan besar seperti karakteristik sungai di daerah pegunungan yang mempunyai aliran sungai besar. Saat ini kondisi sungai tersebut telah berubah dengan adanya pertambangan oleh warga terhadap batu dan pasir. Berikut kondisi sungai desa Ngablak berdasarkan hasil observasi:

1. Air cenderung keruh dengan banyak sampah dibeberapa titik pencemaran.

2. Terjadinya perpindahan aliran air karena karena lebarnya sungai. Hal ini disebabkan karena adanya degradasi di sekitar aliran sungai.

3. Terjadinya penyumbatan di beberapa titik karena sampah yang menumpuk.

4. Tidak adanya pemecah arus sungai alami berupa batu-batuan, karena adanya penambangan batu dan pasir oleh warga. 
Adanya perubahan yang signifikan tersebut tentu sangat mengkhawatirkan karena di sekitar sungai terdapat banyak area persawahan dan perumahan. Dikhawatirkan ketika musim penghujan dapat terjadi longsor di sekitar aliran sungai karena tidak adanya pengendali kecepatan aliran sungai berupa batu-batuan. Selain itu, banyaknya sampah yang menumpuk berupa sampah rumah tangga seperti diappers, plastik dan kaca yang sengaja dibuang warga di beberapa titik aliran sungai menambah lingkungan sekitar sungai semakin memburuk.

\section{Degradasi Daerah Aliran Sungai}

Degradasi Daerah Aliran Sungai (DAS) ditandai semakin meluasnya lahan kritis, erosi pada lereng-lereng curam baik yang digunakan untuk pertanian maupun pemukiman sehingga berdampak luas terhadap lingkungan antara lain banjir yang semakin besar dan frekuensinya meningkat. Selain itu, debit air sungai di musim kemarau yang sangat rendah, percepatan sendimentasi pada sungai dan jaringan irigasi, serta penurunan kualitas air yang mengancam keberlanjutan pembangunan khususnya pembangunan pertanian sekitar.

Di desa Ngablak tepatnya di daerah aliran sungainya belum pernah ada kajian tentang pengelolaan DAS terkait dengan perubahan lingkungan maupun kerusakan yang terjadi. Kajian mengenai DAS menjadi hal yang asing bagi masyarakat dan pemerintah desa karena kurangnya pengetahuan tentang pengelolaan DAS. Hal tersebut dikarenakan kurangnya perhatian dan kepedulian terhadap lingkungan sekitar sungai. Seyogyanya, baik pemerintah desa maupun masyarakat sekitar bersama-sama peduli akan pentingnya pengelolaan DAS dan sadar akan akibat yang ditimbulkan oleh kerusakan DAS itu sendiri.

\section{Pencemaran Sungai oleh Sampah}

Sungai Silungonggo Ngablak sudah menjadi bagian penting dari kehidupan masyarakat sekitarnya. Sejak dulu air sungai banyak dimanfaatkan oleh masyarakat untuk berbagai macam keperluan, seperti untuk mencuci, mandi, maupun sanitasi. Selain itu, hasil alam berupa ikan juga menjadi salah satu pemenuh kebutuhan masyarakat sekitar. Sekarang 
kondisi sungai Silungonggo telah banyak berubah, beberapa tahun terakhir air sungai silungonggo tidak jernih lagi, tidak hanya keruh dan berwarna coklat tetapi airnya juga kerap kali berbau tidak sedap. Berubahnya warna dan bau air sungai dikarenakan oleh polutan atau zat pencemar air, berupa sampah rumah tangga seperti diappers, plastik dan kaca yang sengaja dibuang oleh warga.

Masyarakat desa yang tidak memiliki kesadaran terhadap kelestarian lingkungan menjadikan sungai sebagai tempat pembuangan sampah. Hal tersebut yang menjadikan air sungai tidak dapat digunakan untuk berbagai keperluan sehari-hari dikarenakan kondisi air sungai yang telah tercemar dan kandungan air yang tidak sehat lagi. Selain itu, adanya mitos tentang diappers/ popok bayi yang tidak boleh dibakar atau dimusnahkan menjadi salah satu penyebab masyarakat membuang sampah tersebut ke sungai. Kurangnya edukasi yang benar, kesadaran dan pola pikir masyarakat akan pentingnya menjaga kelestarian lingkungan sungai merupakan faktor yang melatar belakangi adanya pencemaran sungai, khususnya di desa Ngablak. Pencemaran sampah di sungai Silungonggo Ngablak terletak pada titik 500 m sungai B, lokasinya berada di sekitar jembatan yang menghubungkan dukuh Kebolanjam dengan dukuh Plandan. Berikut pemetaan aliran yang tercemar sampah di desa Ngablak.

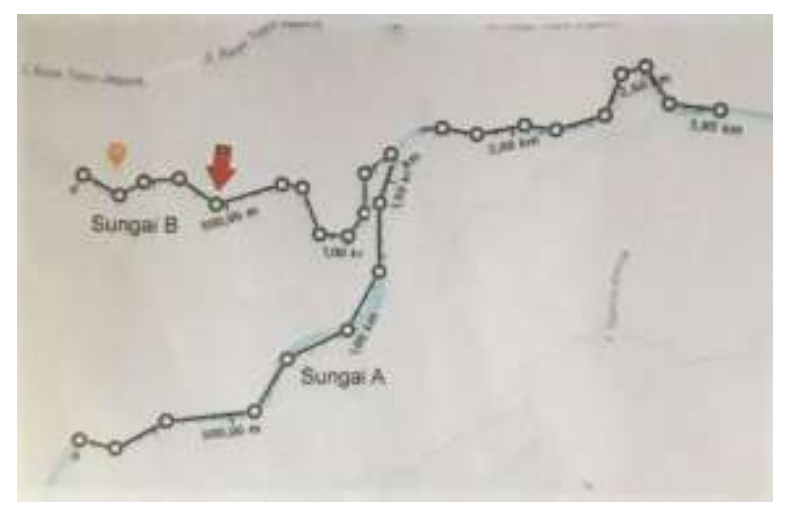

Gambar 1. Pemetaan aliran sungai yang tercemar sampah di desa Ngablak. 


\section{B. Analisis Bentuk Etika Terhadap Lingkungan yang Telah Diterapkan} Komunitas Peduli Sungai

Adanya fenomena penumpukan sampah di sekitar jembatan Kebolanjam yang berada di titik $500 \mathrm{~m}$ sungai B, merupakan salah satu faktor tergeraknya para pemuda yang kini tergabung dalam komunitas peduli sungai. Sampah yang ada di bawah jembatan tersebut berupa sampah rumah tangga, plastik, diappers, kaca dan botol bekas. Selain itu, adanya kiriman sampah dari desa Ngawen dan Plaosan juga turut menyumbang sampah di sungai Silungonggo Ngablak, dengan adanya sampah-sampah tersebut membuat ekosistem sungai tercemar dan berbau menyengat.

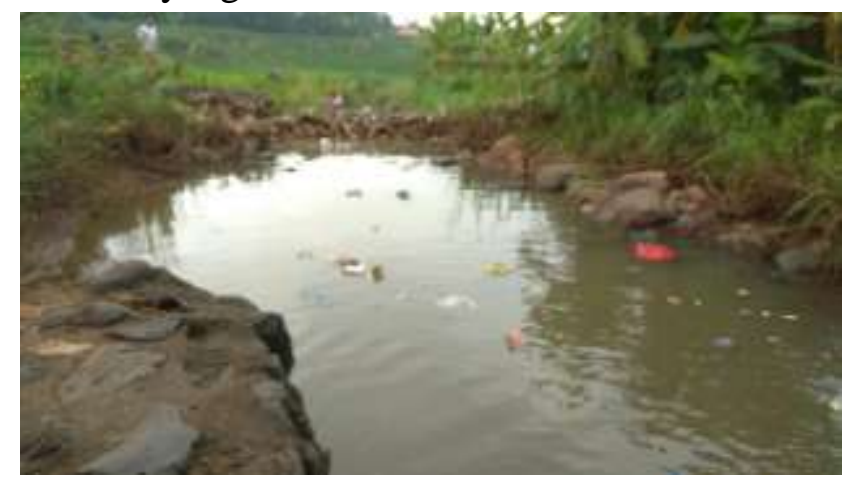

Gambar 2. Sampah di sekitar jembatan Kebolanjam yang berada di titik $500 \mathrm{~m}$ sungai $\mathrm{B}$

Berdasarkan hasil wawancara dengan anggota komunitas, sebelum menerapkan langkah operasional seluruh anggota komunitas melakukan observasi, studi kasus dan mencari informasi terkait penanganan sampah di daerah aliran sungai yang mempunyai kondisi sama dengan sungai Silungonggo. Setelah melakukan pengamatan, studi kasus dan mengevaluasi kelemahan yang ada di lokasi lain, maka komunitas peduli sungai membuat langkah operasional yang tidak hanya menerapkan konsep kebersihan lingkungan tetapi juga keindahan lingkungan.

Komunitas peduli sungai mengambil langkah yang lebih efektif dan kreatif untuk diaplikasikan di area sekitar jembatan Kebolanjam. Langkahlangkah yang dilakukan oleh komunitas untuk mengatasi pencemaran sampah di sekitar aliran sungai sebagai wujud nyata etika terhadap lingkungan dengan konsep bersih dan elok, yaitu: 
1. Melakukan pembersihan sampah di sekitar jembatan dan di bawah jembatan Kebolanjam. Langkah pertama ini merupakan langkah yang harus dilakukan untuk membuat area jembatan Kebolanjam dan area sungai Silungonggo menjadi lebih bersih.

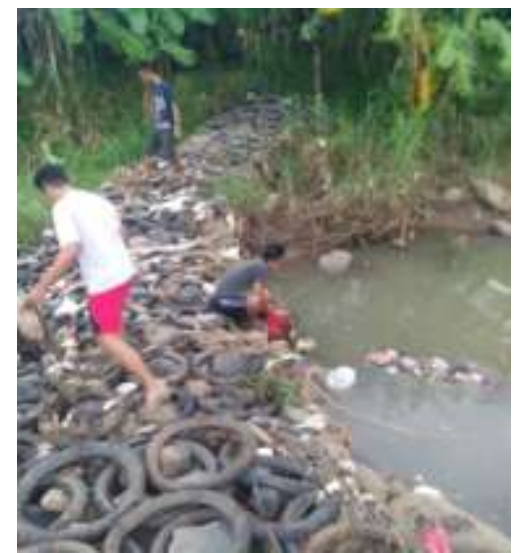

Gambar 3. Pembersihan sampah di sekitar jembatan dan di bawah jembatan Kebolanjam

2. Membuat taman sederhana di sekitar jembatan Kebolanjam sehingga lebih menarik dan dapat menjadi salah satu spot fotografi yang unik. Langkah ini dilakukan karena sebenarnya lokasi di sekitar jembatan mempunyai potensi wisata alam yang menarik berupa bentang sawah yang luas dengan latar belakang gunung Muria. Harapannya, dengan adanya taman di sekitar area jembatan akan membuat orang menjadi malu untuk membuang sampah di sekitar jembatan Kebolanjam. Selain itu, dengan banyaknya pengunjung yang datang, tentu akan membuat orang tidak membuang sampah di tempat tersebut.

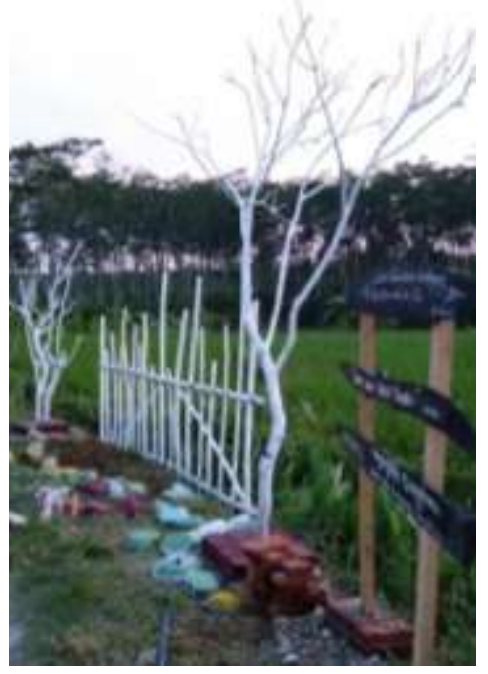

Gambar 4. Taman sederhana di sekitar jembatan Kebolanjam sebagai spot fotografi. 
3. Mengecat jembatan agar lebih menarik dan masyarakat lebih peduli terhadap kebersihan di sekitar jembatan Kebolanjam.

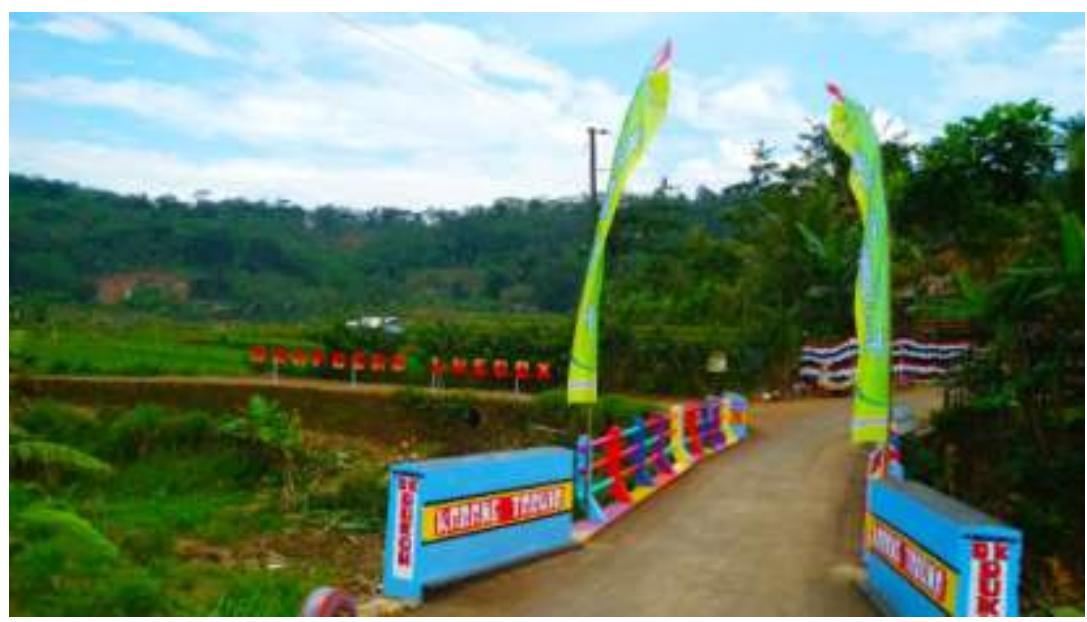

Gambar 5. Mengecat jembatan yang dilakukan oleh anggota komunitas.

4. Memasang papan himbauan larangan membuang sampah. Komunitas lebih memilih menggunakan kata-kata yang sopan, mudah dimengerti dan merupakan bahasa sehari-hari masyarakat.

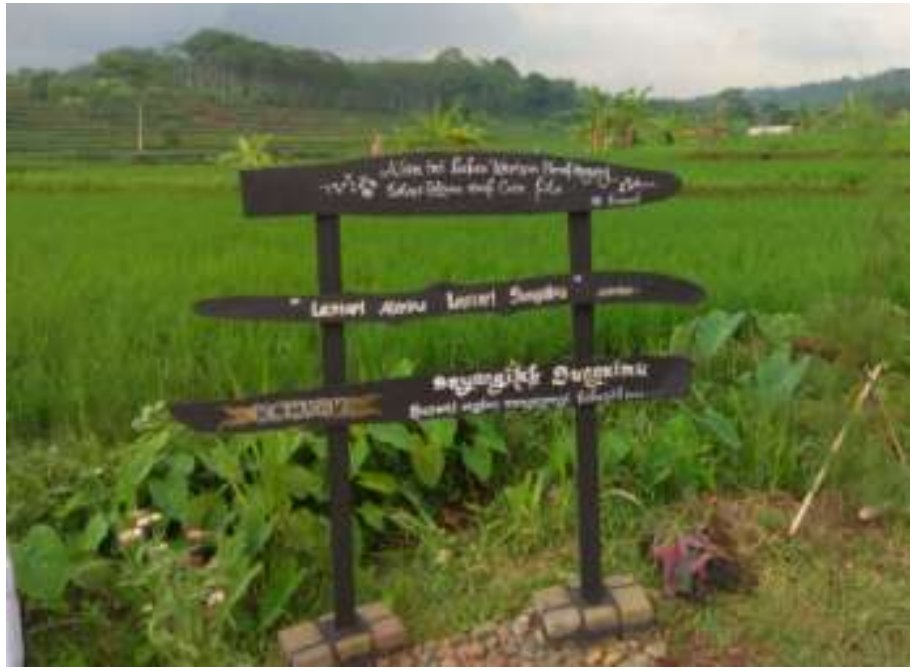

Gambar 6. Papan himbauan/ larangan membuang sampah di sekitar sungai.

Selain konsep bersih dan elok tersebut, komunitas juga membuat pengendali sedimentasi. Bangunan pengendali sedimentasi yang komunitas buat merupakan bendung penahan atau lebih dikenal dengan check dam. Komunitas membangun check dam secara sederhana dengan memanfaatkan batu yang ditata dan diikat dengan ban bekas sepeda motor yang dirangkai 
dengan kawat-kawat. Langkah tersebut dibuat untuk membuat sedimentasi di sekitar jembatan Kebolanjam yang merupakan hulu dari aliran sungai Silungonggo.

Semua usaha yang telah dilakukan komunitas untuk menjaga kelestarian ekosistem sungai dan sekitarnya ternyata memiliki beberapa kendala yang tentunya menghambat proses kegiatan dan hasil yang diinginkan. Adapun kendala yang dihadapi komunitas, antara lain:

1. Terbatasnya pendanaan kegiatan dikarenakan swadaya dari anggota komunitas, sehingga hasil yang diharapkan belum semuanya dapat tercapai.

2. Kurangnya wawasan dan pengetahuan masyarakat akan pentingnya menjaga kelestarian ekosistem sungai.

3. Kurangnya pengetahuan anggota komunitas akan teknis pembuatan bendung penahan, sehingga check dam yang dibuat kurang maksimal.

4. Kurangnya perhatian dan dukungan dari pemerintah desa terkait kegiatan yang dilakukan komunitas dalam upaya melestarikan ekosistem sungai dan perbaikan aliran sungai Silungonggo.

\section{Kegiatan Pengamalan Nilai-Nilai Keislaman yang Dilakukan Komunitas} Peduli Sungai

Pengamalan nilai berkaitan dengan domain afektif yang dimiliki individu. Afektif adalah ranah yang berkaitan dengan sikap dan nilai. Beberapa pakar mengatakan bahwa sikap seseorang dapat diprediksi perubahannya bila seseorang telah memiliki penguasaan kognitif tinggi tinggi. Domain afektif ini oleh Anderson dan Krathwohl (2010) menjadi ranah afektif lebih rinci ke dalam lima kategori, yakni: receiving atau attending, responding, valuing, organization, dan characterization by a value or value complex. Pada implementasinya, komunitas peduli sungai telah mengupayakan beberapa cara agar sikap masyarakat dapat berubah menjadi lebih baik yang tentunya dimulai dengan cara internalisasi melalui majelis taklim dan peningkatan pendidikan agama dalam berbagai forum atau kegiatan masyarakat desa Ngablak secara kontinyu. 
Kategori receiving atau attending (menerima atau memperhatikan) adalah kepekaan seseorang dalam menerima rangsangan dari luar yang datang kepada dirinya dalam bentuk masalah, situasi, gejala, dan lain-lain. Receiving atau attending juga sering diberi pengertian sebagai kemauan untuk memperhatikan suatu kegiatan atau suatu objek. Pada kategori ini masyarakat desa Ngablak dibina agar mereka bersedia menerima himbauan dan larangan membuang sampah dengan pendekatan islam, misalnya melalui ceramah keagamaan atau ceramah di masjid-masjid sekitar dengan memberikan contoh nilai-nilai keislaman dalam kehidupan sehari-hari sehingga mudah diterima masyarakat. Selain itu juga melalui peningkatan pendidikan agama dalam berbagai forum atau kegiatan masyarakat desa Ngablak, melakukan diskusi sederhana dengan masyarakat sekitar dan semua upaya tersebut dilakukan secara kontinyu.

Kategori responding (menanggapi) mengandung arti adanya partisipasi aktif. Kemampuan menanggapi adalah kemampuan yang dimiliki oleh seseorang untuk mengikutsertakan dirinya secara aktif dan membuat reaksi terhadap fenomena tertentu. Kategori ini setingkat lebih tinggi dari kategori receiving, pada tingkat ini masyarakat desa Ngablak telah tumbuh keinginan untuk mempelajari lebih jauh atau menggali lebih dalam tentang berbagai nilai ajaran Islam. Masyarakat memberikan respon positif dengan mentaati himbauan dan larangan membuang sampah di sungai karena sadar menjaga kebersihan dan melestarikan lingkungan merupakan salah satu bentuk perwujudan nilai-nilai islam.

Kategori valuing (menilai atau menghargai) artinya memberikan nilai atau memberikan penghargaan terhadap suatu kegiatan atau objek, sehingga apabila kegiatan itu tidak dikerjakan, dirasakan akan membawa kerugian atau penyesalan. Kategori ini lebih tinggi dari receiving dan responding, karena pada kategori ini diindikasikan bahwa dalam diri masyarakat telah tumbuh kemauan yang kuat untuk mempraktikan nilai- nilai ajaran Islam dalam kehidupan sehari-hari baik dalam kehidupan pribadi, dalam keluarga, atau di tengah-tengah masyarakat. Pada tahap ini, masyarakat mulai menghargai lingkungan sekitar, meskipun tidak ada himbauan atau larangan 
membuang sampah, dimanapun ia berada akan selalu memperhatikan kebersihan lingkungan sekitar serta tidak merusak fasilitas umum.

Kategori organization (mengatur atau mengorganisasikan) artinya kemampuan untuk mempertemukan perbedaan nilai sehingga terbentuk nilai baru yang lebih universal, yang membawa kepada kebaikan umum. Mengatur atau mengorganisasikan ini merupakan kategori sikap atau nilai yang lebih tinggi dari receiving, responding, dan valuing. Sedangkan, characterization by a value or value complex (karakterisasi dengan suatu nilai atau nilai yang bersifat kompleks), yaitu keterpaduan semua sistem nilai yang telah dimiliki seseorang yang mempengaruhi pola kepribadian dan tingkah lakunya. Pada proses internalisasi nilai telah menempati tempat tertinggi dalam suatu hierarki nilai. Ini merupakan tingkatan afektif tertinggi, karena dalam konteks ini berarti sikap batin masyarakat telah memiliki philosophy of life yang mapan terkait dengan nilai-nilai Islam sebagai petunjuk kehidupan. Pada tahap ini, masyarakat telah memiliki kebulatan sikap yang utuh untuk menjadikan ajaran Islam sebagai pegangan hidup dalam seluruh aspek kehidupannya (Sarbini, 2010).

Berdasarkan beberapa tingkatan ranah afektif tersebut, sikap yang ditunjukan masyarakat terkait upaya yang telah dilakukan komunitas berada pada tahap responding, karena untuk mencapai tingkatan sikap yang lebih tinggi tentunya membutuhkan peran pemerintah desa dan pihak-pihak penting lainnya yang lebih kompeten. Pembahasan tersebut merupakan upaya yang dilakukan komunitas dalam mengamalkan nilai-nilai keislaman yang berupa internalisasi melalui majelis taklim, peningkatan pendidikan agama dalam berbagai forum atau kegiatan masyarakat desa Ngablak dan diskusi sederhana dengan anggota masyarakat. Sedangkan, nilai-nilai keislaman yang perlu ditanamkan dalam diri masyarakat terkait dengan usaha pemeliharaan kebersihan lingkungan yaitu penanaman nilai ilahiyah dan nilai insaniyah (Hermawansyah dan Suryani, 2016).

Nilai Ilahiyah merupakan sebuah substansi nilai yang berpedoman pada hukum yang benar dan jelas tidak hanya diucapkan oleh lisan akan tetapi mampu dirasakan dengan iman, jika manusia mampu merinci apa saja 
wujud nyata atau substansi ketuhanan maka akan di dapatkan nilai-nilai keagamaan pribadi yang sangat penting yang harus ditanamkan pada setiap pribadi manusia. Nilai ilahiyah berarti mampu menunjukan sikap yang penuh kepercayaan kepada Allah sebagai Tuhan yang menciptakannya, sehingga seseorang percaya bahwa Allah Maha Mengetahui apapun yang dilakukan oleh manusia. Adanya nilai ini di dalam diri manusia akan membuat dirinya selalu mengontrol tindakan atau perilakunya karena sadar Allah selalu mengawasinya di manapun manusia berada. Bagi masyarakat desa Ngablak, dimilikinya nilai ilahiyah akan menyadarkan mereka bahwa meskipun tidak ada orang yang melihat ketika mereka membuang sampah di lingkungan sungai, tetapi Allah mengetahuinya dan Allah tidak menyukai orang-orang yang tidak menjaga kebersihan serta keindahan. Penanaman sikap ilahiyah yang baik akan membuat lingkungan menjadi bersih, nyaman dan aman.

Selain nilai Ilahiyah, ada nilai Insaniyah yang perlu ditanamkan dalam diri masyarakat. Nilai Insaniyah substansi nilai yang berpedoman pada akal sehat, hati nurani yang berpijak pada idealisme hidup yang dimiliki sebagai kekuatan untuk menghadirkan budi luhur dalam kepribadian masyarakat, dengan kepribadian yang kuat, masyarakat tidak gampang melakukan segala hal yang buruk di lingkungannya dan mampu membangun komunikasi dalam kehidupan sosial secara cinta kasih kepada sesama tanpa saling mengklaim satu sama lainnya dan tidak saling menyalahkan. Nilai Insaniyah merupakan kekuatan untuk mengikat ukwah sesama dan memperkokoh silaturahmi dan kehidupan sosial, sebab desa Ngablak merupakan desa yang memiliki pluralisme cukup tinggi sehingga perlu dibangun interaksi sosial yang baik dan harmonis. Nilai Insaniyah sangat penting ditanamkan pada masyarakat desa Ngablak mengigat lingkungannya merupakan lingkungan yang memiliki beberapa agama dan konsep tuhan yang berbeda, maka dengan nilai insaniyah yang baik dapat membangun cinta kedamain dan keharmonisan umat. Harapannya keharmonisan ini terus berlanjut tanpa ada perpecahan satu dengan lainnya, sehingga seluruh anggota masyarakat benar-banar saling bahu menbahu dalam melestarikan lingkungan sekitar sungai. 


\section{SIMPULAN}

Hasil penelitian diperoleh bahwa adanya fenomena penumpukan sampah di sekitar jembatan Kebolanjam yang berada di titik 500 m sungai B, komunitas peduli sungai mengambil langkah operasional yang efektif dan kreatif untuk mengatasi pencemaran sampah di sekitar aliran sungai sebagai wujud nyata etika terhadap lingkungan dengan konsep bersih dan elok, yaitu: melakukan pembersihan sampah di sekitar jembatan dan di bawah jembatan Kebolanjam, membuat taman sederhana di sekitar jembatan Kebolanjam sehingga lebih menarik dan dapat menjadi salah satu spot fotografi yang unik, mengecat jembatan agar lebih menarik dan masyarakat lebih peduli terhadap kebersihan di sekitar jembatan Kebolanjam, memasang spanduk himbauan/ larangan membuang sampah, komunitas juga membuat pengendali sedimentasi berupa check dam secara sederhana. Selain itu, komunitas juga tidak melupakan upaya untuk perbaikan sikap masyarakat melalui internalisasi nilai-nilai islam (nilai ilahiyah dan insaniyah) melalui majelis taklim dan peningkatan pendidikan agama dalam berbagai forum atau kegiatan masyarakat desa Ngablak secara keberlanjutan.

\section{DAFTAR PUSTAKA}

Anderson, Lorin W \& David R. Krathwohl. (2010). Pembelajaran, Pengajaran dan Asesmen (Terjemahan Agung Prihantoro). New York: Addison Wesley Longman.

Desfandi, Mirza. (2015). Mewujudkan Masyarakat Berkarakter Peduli Lingkungan Melalui Program Adiwiyata. Social Science Education Journal, 2 (1), 2015, 31-37.

Halid, Idham, Prabang Setyono dan Sunarto (2014). Implementasi Nilai-Nilai Islam dalam Sikap Ramah Lingkungan untuk Mewujudkan Masyarakat Sadar Lingkungan Melalui Gerakan Pondok Pesantren. Jurnal Ekosains, Vol. VI, No. 1.

Harahap, Rabiah Z. (2015). Etika Islam Dalam Mengelola Lingkungan Hidup. Jurnal Edutech Vol.1 No 1 Maret 2015, ISSN : 2442-6024, E-ISSN : 24427063

Hermawansyah dan Suryani. (2016). Internalisasi Nilai-Nilai Keislaman Pada Anak-Anak Para Muallaf. Jurnal Studi Keislaman Dan Ilmu Pendidikan Volume 5, Nomor 1, Mei 2017; P-ISSN 2338-2325; E-ISSN 2540-9697. 
Ramdhani, Deddy (2015). Penanaman Nilai-Nilai Keislaman Dalam Pendidikan Agama Islam di Pondok Pesantren Darusy Syahadah Simo Boyolali Tahun Pelajaran 2015/2016. Naskah Publikasi Fakultas Agama Islam Universitas Muhammadiyah Surakarta.

Rusdina, A. (2015). Membumikan Etika Lingkungan Bagi Upaya Membudayakan Pengelolaan Lingkungan yang Bertanggung Jawab. Jurnal Kajian Islam, Sains dan Teknologi, Juli 2015 Volume IX No. 2 ISSN 1979-8911.

Rusmadi (2016). Ecosophy Islam: Studi Tematis-Kontekstual Nilai-Nilai Etika Lingkungan dalam Islam. Jurnal Studi Masyarakat Religi Dan Tradisi Volume 02 No.02

Sarbini, Ahmad. (2010). Internalisasi Nilai Keislaman Melalui Majelis Taklim. Jurnal Ilmu Dakwah No. 16 Vol. 5.

Sugiyono. (2016). Metode Penelitian Pendidikan: Pendekatan Kuantitatif, Kualitatif, dan R\&D. Bandung: Alfabeta.

Suharsimi Arikunto. (2006). Prosedur Penelitan Suatu Pendekatan Praktek, Jakarta: PT. Rineka Cipta.

Sukmadinata, Nana Syaodih. (2006). Metode Penelitian Pendidikan. Bandung: PT. Remaja Rosdakarya. 